\title{
Metabolism of cyclic GMP in peritoneal macrophages of rat and guinea pig $^{\star}$
}

\author{
Marcin Kobiałka, Hanna Witwicka, Jakub Siednienko and Wojciech A. Gorczyca ${ }^{\varpi}$ \\ Laboratory of Signaling Proteins, L. Hirszfeld Institute of Immunology and Experimental \\ Therapy, Polish Academy of Sciences, Wroctaw, Poland
}

Received: 26 June, 2003; revised: 07 August, 2003; accepted: 12 August, 2003

Key words: cyclic nucleotides, guanylyl cyclases, protein kinases, phosphodiesterases, signal transduction, macrophages, rat, guinea pig

\begin{abstract}
The aim of our studies was to establish which enzymes constitute the "cGMP pathway" in rat and guinea pig peritoneal macrophages (PM). We found that in guinea pig PM synthesis of the nucleotide was significantly enhanced in response to activators of soluble guanylyl cyclase (sGC) and it was only slightly stimulated by specific activators of particulate guanylyl cyclases (pGC). In contrast, rat PM responded strongly to atrial natriuretic peptide (ANP), the activator of pGC type A. The rat cells synthesized about three-fold more cGMP than an equal number of the guinea pig cells. The activity of phosphodiesterases (PDE) hydrolyzing cGMP was apparently regulated by cGMP itself in PM of both species and again it was higher in the rat cells than in those isolated from guinea pig. However, guinea pig PM revealed an activity of $\mathrm{Ca}^{2+} /$ calmodulin-dependent PDE1, which was absent in the rat cells. Using Western blotting analysis we were unable to detect the presence of cGMP-dependent protein kinase 1 (PKG1) in PM isolated from either species. In summary, our findings indicate that particulate GC-A is the main active form of GC in the rat PM, while in guinea pig macrophages the sGC activity dominates. Since the profiles of the PDE activities in rat and guinea pig PM are also different, we conclude that the mechanisms regulating cGMP metabolism in PM are species-specific. Moreover, our results suggest that targets for cGMP other than PKG1 should be present in PM of both species.
\end{abstract}

\footnotetext{
${ }_{\text {This work was supported by the State Committee for Scientific Research (KBN, Poland) grants No. } 6}$ P04A 05918 and 3 P04A 05922 to M.K. and W.A.G.

${ }^{\otimes}$ Corresponding author: Wojciech A. Gorczyca, Laboratory of Signaling Proteins, L. Hirszfeld Institute of Immunology and Experimental Therapy, R. Weigla 12, 53-114 Wrocław, Poland; phone: (48 71) 337 1172; fax: (48 71) 337 1382; e-mail: gorczyca@immuno.iitd.pan.wroc.pl

Abbreviations: ANP, atrial natriuretic peptide; CaM, calmodulin; CNP, natriuretic peptide type C; GC, guanylyl cyclase; IBMX, 3-isobutyl-1-methylxanthine; PDE, phosphodiesterases; PKG, cGMP-regulated protein kinase; pGC, particulate GC; PM, peritoneal macrophages; sGC, soluble GC; SNAP, $S$-nitroso-acetylpenicillamine; SNP, sodium nitroprusside; STa, heat-stable enterotoxin from Escherichia coli.
} 
The intracellular concentration of cGMP increases after activation of guanylyl cyclases (GC) and is regulated by the activity of phosphodiesterases (PDE). The cGMP signal is in turn transmitted to other proteins of which cGMP-dependent protein kinase 1 (PKG1) appears to be the most ubiquitous effector (Lohmann et al., 1997; Lucas et al., 2000). Guanylyl cyclases exist as cytosolic (soluble, sGC) or membrane-bound (particulate, pGC) enzymes (Bellamy \& Garthwaite 2002; Kobiałka \& Gorczyca, 2000). Both forms differ in structure, mechanisms of activation, subcellular localization, and supposedly cellular effects of their activities are also distinct (Ivanova et al., 2001; Zolle et al., 2000). The soluble cyclases are activated by nitric oxide (Koesling et al., 1998), which is a known modulator of immune responses (Hill et al., 1996; Paolucci et al., 2000). Three isoforms (GC-A, GC-B, and GC-C) of particulate cyclases are receptors for peptide hormones and are activated either by natriuretic peptides (GC-A, GC-B) or by guanylins and bacterial heat-stable enterotoxins (GC-C) (Kobiałka \& Gorczyca, 2000; Vaandrager, 2002). Two other particulate cyclases (GC-E and GC-F), found mainly in the photoreceptor cells of the vertebrate retina, are regulated by intracellular interaction with calcium-binding proteins named guanylyl cyclase-activating proteins (Dejda et al., 2002; Gorczyca et al., 2003; Kobiałka \& Gorczyca, 2000). Cyclic nucleotide phosphodiesterases catalyze hydrolysis of cyclic $3^{\prime}, 5^{\prime}$-nucleoside monophosphates (cAMP and/or cGMP) to respective 5 '-nucleoside monophosphates. They are classified into 11 different families (PDE1-11), which differ in structure, substrate specificity, mechanism of activation and exhibit distinct tissue, cellular, and subcellular expression (Francis et al., 2000; Soderling \& Beavo, 2000). Among the multiple isoforms of phosphodiesterases, enzymes belonging to seven families (PDE1, 2, 5, 6, 9-11) are able to hydrolyze cGMP (Francis et al., 2000; Witwicka et al., 2002).
The role and metabolism of cGMP in cells of the immune system, including macrophages, have not been extensively explored and are still poorly understood. On the contrary, the participation of cAMP in chemotaxis, phagocytosis, presentation of antigens, and secretion of cytokines and other inflammatory mediators is well documented for mononuclear phagocytes (Galea \& Feinstein 2000; Germain et al., 1998; Hahn et al., 1998; Jaramillo \& Olivier 2002; Turner et al., 1993). Also cGMP has been shown to be involved in several of these processes (Connelly et al., 2003; Heinloth et al., 2002; Kamisato et al., 1997; Ke et al., 2001; Kiemer et al., 2000; Kiemer \& Vollmar, 1998; Mattana \& Singhal, 1993; Tamion et al., 1999; Yoshioka et al., 2003). However, the available data on the expression of different $\mathrm{GC}$ and PDE isoforms in macrophages are incomplete and often contradictory. Activities of soluble, particulate or both forms of guanylyl cyclases have been reported to be present in monocytes/macrophages of various species (Bilzer et al., 1999; Hortelano et al., 1993; Houdijk et al., 1990; O’Dorisio et al., 1984; Syrovets et al., 1997; Witwicka et al., 2002). There are only few reports concerning the presence of cGMP-hydrolyzing PDEs in macrophages (Prpic et al., 1993; Tenor et al., 1995; Turner et al., 1993; Witwicka et al., 2002). It has also been noted that expression profiles of GC and PDE isoforms change during maturation of monocytes to macrophages (O’Dorisio et al., 1984; Gantner et al., 1997). Since the expression of enzymes participating in cGMP signaling varies during development of macrophages, the role of cGMP in these cells is possibly also variable. Thus, identification of the enzymes constituting the "cGMP pathway" appears to be critical for understanding the cellular effects of cGMP. Here we report results of experiments that have addressed the question which isoforms of GCs, PDEs, and PKGs may contribute to cGMP signaling in inflammatory 
macrophages isolated from peritoneal cavity of guinea pig and rat.

\section{MATERIALS AND METHODS}

Reagents. Acrylamide, bis $\left(N, N^{\prime}\right.$-methylene-bis-acrylamide), ammonium persulfate, SDS, TEMED, and Bromophenol Blue were purchased from Fluka (Buchs, Germany); CNBr-activated Sepharose 4B was from Amersham Pharmacia Biotech AB (Uppsala, Sweden). Alkaline phosphatase conjugated anti-rabbit IgG and BCIP/NBT color development substrate were purchased from Promega (Madison, WI, U.S.A.). $\left[{ }^{3} \mathrm{H}\right] \mathrm{cGMP}$ was from NEN-Polatom (Otwock, Poland). Antibodies specific to PKG1 were purchased from StressGen Biotechnologies (Victoria, BC, Canada). ANP and CNP were obtained from Calbiochem-Novabiochem (Darmstadt, Germany). Aprotinin, cGMP, EDTA, EGTA, GTP, Hepes, IBMX, leupeptin, pepstatin A, PMSF, soybean trypsin inhibitor, STa, and other chemicals were from Sigma Chemical Co. (St. Louis, MO, U.S.A.).

Animals. Wistar male rats (150-200 g) and male guinea pigs (300 g) were obtained from the colony at the Institute of Immunology and Experimental Therapy (Wrocław, Poland). The animals were treated in accordance with the procedures approved by the Local Ethics Committee For Animal Experimentation in Wrocław.

Cells. Peritoneal macrophages were prepared as previously described (Gorczyca et al., 1989; Witwicka et al., 2002). Thioglycollate was intraperitoneally injected to rats and guinea pigs (rat $10 \mathrm{ml}$, guinea pig $20 \mathrm{ml}$ ). Four days later the animals were sacrificed and peritoneal exudate cells were harvested. The cells were centrifuged and remaining erythrocytes lysed by osmotic shock. After next two washes with Hank's balanced salt solution (HBSS), the cells were resuspended in RPMI 1640 containing $2 \%$ heat inactivated autologous serum and non-adherent cells were removed. More than $95 \%$ of the isolated cells were macrophages as determined by morphological evaluation and their viability was always $>95 \%$ as determined by trypan blue exclusion.

Induction of intracellular cGMP. Induction of cGMP in cells was performed according to a procedure described elsewhere (Kurowska et al., 2002). Briefly, the macrophages were transferred into a 48-well microplate and allowed to rest for $30 \mathrm{~min}$ at $37^{\circ} \mathrm{C}$ before the experiments. Each well contained $2.5 \times 10^{5}$ cells in a final volume of $0.5 \mathrm{ml}$. An inhibitor (IBMX) of PDE was added, and after 10 subsequent minutes of incubation at $37^{\circ} \mathrm{C}$ the cells were supplemented with activators (SNP, SNAP, ANP, CNP or STa) of guanylyl cyclases. All samples were prepared in quadruplicate. After 30 min incubation, the reaction was terminated, the cells were disintegrated, and intracellular content of cGMP was determined.

Measurement of intracellular cGMP. Accumulated cGMP was measured using immunoenzymatic assay based on polyclonal antibodies highly specific for cGMP (Kobiałka et al., 2002). Antibodies were raised in rabbits by immunization of the animals with conjugates of human serum albumin (HSA) and cGMP (HSA-cGMP) according to the procedure described by Horton \& Baxendale (1995). To prevent the undesired cross-reactivity, the obtained antisera were adsorbed using columns containing HSA-cAMP conjugates (prepared in the same way as HSA-cGMP) coupled to Sepharose 4B. The antibodies not bound to the column were evaluated for specificity and then used in the assay. The assay was performed in 96-well microplates (MaxiSorp plates, Nalge Nunc International, Naparville, IL, U.S.A.) coated with $0.5 \mu \mathrm{g} / \mathrm{ml}$ conjugates of thyroglobulin and cGMP in phosphate buffered saline (PBS) and blocked with $0.2 \%$ casein in PBS. To improve the sensitivity, the samples and standard solutions of cGMP were acetylated before the assay by addition of a $2: 1(\mathrm{v} / \mathrm{v})$ mixture of triethylamine and acetic 
anhydride. The acetylated or non-acetylated samples were preincubated with antiserum for $2 \mathrm{~h}$ at $4^{\circ} \mathrm{C}$, then transferred into microplate wells and incubated for $1 \mathrm{~h}$ at $4^{\circ} \mathrm{C}$. The supernatants with antisera were removed, the plates were washed and, in order to detect the bound primary antibodies, incubated for $1 \mathrm{~h}$ at room temperature with anti-rabbit IgG goat antibodies conjugated to horseradish peroxidase. The color reaction was developed using tetramethylbenzidine as a substrate and the absorbance of each well was measured in a Dynatech MR5000 plate reader. The amount of cGMP in the sample was calculated from a calibration curve prepared for each plate separately.

Preparation of subcellular fractions. The procedures were performed at $4^{\circ} \mathrm{C}$ according to Germain et al. (1998). Freshly isolated macrophages were resuspended at $2.5 \times 10^{8}$ cells $/ \mathrm{ml}$ in homogenization buffer $(10 \mathrm{mM}$ Tris/ $\mathrm{HCl}, \mathrm{pH} 7.5$, containing $1 \mathrm{mM} \mathrm{MgCl}_{2}$, $1 \mathrm{mM}$ DTT, $5 \mu \mathrm{M}$ pepstatin A, $10 \mu \mathrm{M}$ leupeptin, $50 \mu \mathrm{M}$ PMSF, $10 \mu \mathrm{M}$ soybean trypsin inhibitor and $1 \mathrm{mM}$ benzamidine) and sonicated on ice. The homogenate was centrifuged at $100000 \times \boldsymbol{g}$ for $1 \mathrm{~h}$. The supernatant was collected and the pellet resuspended in equal volume of homogenization buffer. The supernatants and resuspended pellets were used in determination of PDE activity as the soluble and particulate fractions, respectively.

Determination of phosphodiesterase activity (PDE assay). The PDE activity was determined in the obtained fractions (soluble or particulate) at $37^{\circ} \mathrm{C}$ according to the procedure described previously (Witwicka et al., 2002). Briefly, the reaction samples ( $100 \mu \mathrm{l}$ final volume) were prepared in duplicate and contained $40 \mathrm{mM}$ Hepes, $\mathrm{pH} 7.6,5 \mathrm{mM} \mathrm{MgCl}_{2}$, $0.1 \%$ bovine serum albumin, $0.5 \mu \mathrm{M}$ $\left[{ }^{3} \mathrm{H}\right] \mathrm{cGMP}$ (40 $000 \mathrm{cpm}$ ), activators and inhibitors. The reaction was initiated by addition of $10 \mu \mathrm{l}$ of the tested fraction containing approximately $20 \mu \mathrm{g}$ of protein, and was terminated after $15 \mathrm{~min}$ by boiling the samples. After separation of the product from the substrate, the radio- activity of the product was measured in the Wallac-LKB liquid scintillation counter.

SDS/PAGE and Western blotting. Cellular extracts, containing 20-40 $\mu \mathrm{g}$ of protein as determined by the BCA Protein Assay, were resolved under reducing conditions in SDS/PAGE using $12.5 \%$ acrylamide gels and electrotransferred onto nitro-cellulose (Schleicher \& Schuell, Dassel, Germany). The membranes were then blocked with $2 \%(\mathrm{w} / \mathrm{v})$ casein and incubated for $1.5 \mathrm{~h}$ with anti-PKG1 antibodies. After washing with $50 \mathrm{mM}$ Tris, $\mathrm{pH}$ 7.5, $150 \mathrm{mM} \mathrm{NaCl}, 0.05 \%$ Tween 20 (TBST) and subsequently three times with 50 $\mathrm{mM}$ Tris, $\mathrm{pH} 7.5,150 \mathrm{mM} \mathrm{NaCl}$ (TBS), the membranes were incubated with anti-rabbit IgG goat antibodies conjugated to alkaline phosphatase and protein bands were visualized using NBT/BCIP-based substrate.

\section{RESULTS}

\section{Synthesis of cGMP in peritoneal macrophages}

In order to establish which isoforms of GCs are responsible for cGMP synthesis in guinea pig and rat peritoneal macrophages, the cells isolated from both species were treated with specific activators of soluble and particulate guanylyl cyclases (Fig. 1). The experiments were performed in the presence of IBMX, a non-selective PDE inhibitor, to prevent hydrolysis of the synthesized nucleotide. The levels of cGMP in unstimulated (control) guinea pig as well as rat PM were similar $(0.15 \pm 0.01$ and $0.12 \pm 0.02 \mathrm{pmol} / 10^{6}$ cells per $30 \mathrm{~min}$, respectively) indicating rather low basal activity of GC in PM of both species.

Stimulation of guinea pig PM with SNP or SNAP caused a significant (above 10-fold) increase in the level of intracellular cGMP. At the same time neither SNP nor SNAP were able to induce cGMP synthesis in rat macrophages (Fig. 1A). 
Treatment of rat PM with ANP resulted in a large, about 40-fold higher than the control value, accumulation of cGMP (Fig. 1B). In contrast to the rat cells, ANP had no effect on cGMP formation in guinea pig PM. However,

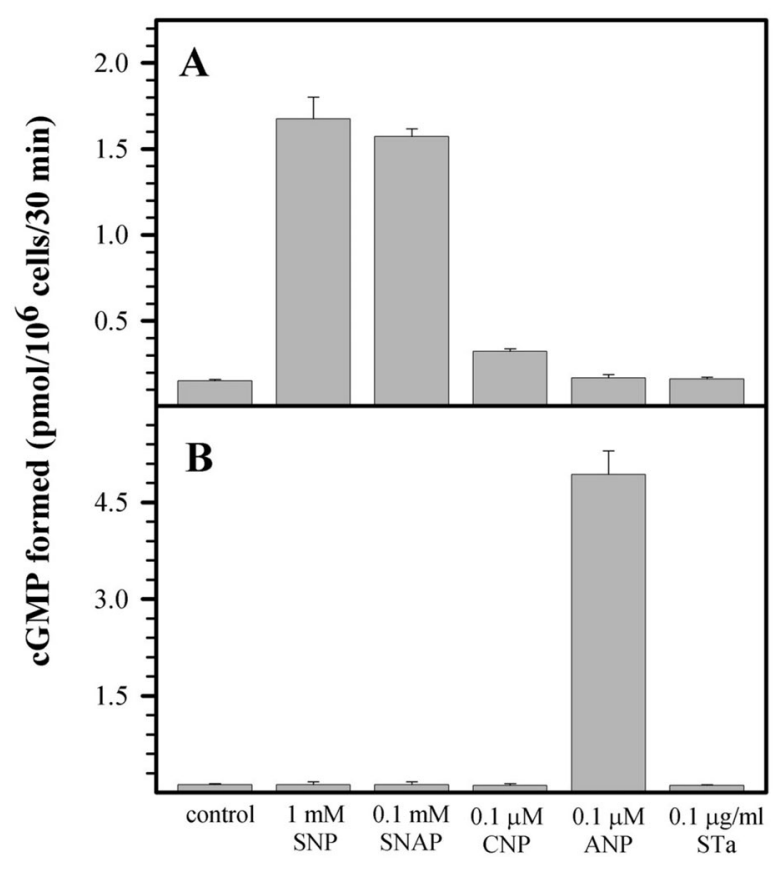

Figure 1. Synthesis of cGMP in guinea pig (A) and rat (B) peritoneal macrophages in response to activators of soluble and particulate GCs.

Cells were stimulated for $30 \mathrm{~min}$ with indicated concentrations of activators of soluble (SNP, SNAP) and particulate (ANP, CNP, STa) guanylyl cyclases in the presence of $0.5 \mathrm{mM}$ IBMX and intracellular cGMP was determined as described in Materials and Methods. The data shown are the means \pm S.E. of three independent measurements. The results are expressed as picomoles of cGMP formed during $30 \mathrm{~min}$ in samples containing $1 \times 10^{6}$ cells.

ANP applied at the same concentrations to guinea pig kidney cells caused an increase of the cGMP level indicating that the peptide was able to induce cGMP synthesis in guinea pig cells other than macrophages (not shown). Interestingly, guinea pig macrophages responded with an over two-fold increase of cGMP synthesis to natriuretic peptide type $\mathrm{C}$ (CNP), which is an activator of particulate GC-B. Heat-stable enterotoxin (STa), a known activator of GC-C, did not affect cGMP synthesis in macrophages of either species.

We also examined whether the presence of a PDE inhibitor is indeed required to prevent degradation of synthesized cGMP. The accumulation of the nucleotide in PM of both species was significantly diminished in the absence of IBMX (Fig. 2).

\section{PDE activity in cellular fractions of guinea pig and rat $\mathrm{PM}$}

The intracellular concentration of synthesized cGMP is mainly controlled by the activity of phosphodiesterases and also by extrusion of the nucleotide outside the cell. The latter possibility could be ignored because more than $90 \%$ of synthesized cGMP remained inside the cells (not shown). Since the results described above clearly showed that in intact PM a PDE activity is present (Fig. 2), we attempted to determine how it may be regulated and how it is distributed in the cells of both species.

The PDE activity was measured in the soluble and particulate fractions of rat and guinea pig PM using $\left[{ }^{3} \mathrm{H}\right] \mathrm{cGMP}$ as substrate. Two different concentrations of cGMP were used to test if cGMP-hydrolyzing PDEs might be cGMP-regulated. In order to verify whether $\mathrm{Ca}^{2+}$ may affect hydrolysis of cGMP, the PDE activity was measured in soluble fractions of guinea pig and rat PM in the presence of $\mathrm{Ca}^{2+} / \mathrm{CaM}$ or in the presence of EGTA. The results obtained are summarized in Table 1.

At $5 \mu \mathrm{M}$ cGMP, the PDE activity in the soluble fraction exceeded about 14 -fold in rat and 6.5-fold in guinea pig PM the values measured at $0.5 \mu \mathrm{M}$ cGMP. Hydrolysis of cGMP depended on the presence of $\mathrm{Ca}^{2+} / \mathrm{CaM}$ in guinea pig but not in rat PM. In the particulate (membrane) fraction of PM the activity of cGMP hydrolyzing enzymes was about one order of magnitude lower than in the soluble fraction but again it depended on cGMP concentration. In both fractions hydrolysis of cGMP was strongly inhibited by $0.2 \mathrm{mM}$ 

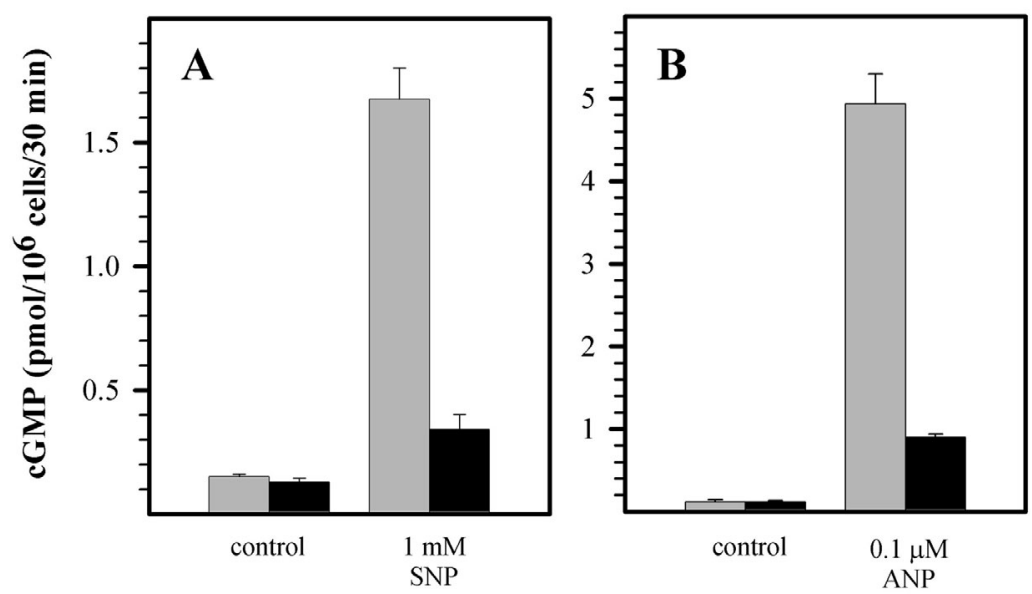

Figure 2. Effect of PDE inhibitor on cGMP accumulation in guinea pig (A) and rat (B) PM.

Cells were incubated for 30 min without (control) or with indicated GC activators, either in the absence (black bars) or in the presence of $0.5 \mathrm{mM}$ IBMX (gray bars), and then intracellular content of cGMP was determined as described in Materials and Methods. Other details are the same as in the legend to Fig. 1.

IBMX which additionally proved the presence of cGMP-hydrolyzing PDEs in PM.

Taken together, these results showed that in macrophages of both species cGMP was hydrolyzed by cGMP-dependent PDEs, which were present mainly in the cytosolic fraction.
In guinea pig $\mathrm{PM}$ an activity of $\mathrm{Ca}^{2+} / \mathrm{CaM}-\mathrm{de}-$ pendent PDE1 was present, which was absent in rat PM. It should also be noted that the PDE activity toward cGMP was markedly higher in the rat cells than in those obtained from guinea pig.

Table 1. Activity of cGMP-hydrolyzing phosphodiesterases in soluble and particulate fractions of guinea pig and rat PM

\begin{tabular}{|c|c|c|c|c|c|}
\hline & \multicolumn{4}{|c|}{$\begin{array}{c}\text { PDE activity } \\
(\mathrm{pmol} / \mathrm{min} / \mathrm{mg} \text { of protein) }\end{array}$} \\
\hline & & \multicolumn{2}{|c|}{ Rat } & \multicolumn{2}{|c|}{ Guinea pig } \\
\hline & & $(+)$ IBMX & (-) IBMX & $(+)$ IBMX & $(-)$ IBMX \\
\hline \multirow{4}{*}{ 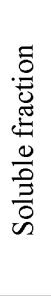 } & $0.5 \mu \mathrm{M} \mathrm{cGMP}$ & $5.41 \pm 0.49$ & $24.04 \pm 1.55$ & $2.61 \pm 2.13$ & $4.41 \pm 0.03$ \\
\hline & $5 \mu \mathrm{M}$ cGMP & $54.65 \pm 2.01$ & $332.92 \pm 50.13$ & $2.22 \pm 0.13$ & $28.46 \pm 0.89$ \\
\hline & $\begin{array}{l}0.5 \mu \mathrm{M} \text { cGMP } \\
+\mathrm{Ca}^{2+} / \mathrm{CaM}\end{array}$ & $5.52 \pm 1.89$ & $29.70 \pm 7.03$ & $4.33 \pm 0.51$ & $8.95 \pm 0.43$ \\
\hline & $\begin{array}{l}0.5 \mu \mathrm{M} \text { cGMP } \\
+ \text { EGTA }\end{array}$ & $6.81 \pm 0.55$ & $27.28 \pm 3.14$ & $1.98 \pm 0.54$ & $4.0 \pm 1.12$ \\
\hline \multirow{2}{*}{ 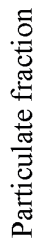 } & $0.5 \mu \mathrm{M} \mathrm{cGMP}$ & $0.61 \pm 0.16$ & $0.70 \pm 0.23$ & $0.31 \pm 0.08$ & $0.75 \pm 0.01$ \\
\hline & $5 \mu \mathrm{M}$ cGMP & $0.54 \pm 0.16$ & $23.84 \pm 9.72$ & $0.35 \pm 0.18$ & $3.75 \pm 0.26$ \\
\hline
\end{tabular}

Cells were homogenized, homogenates resolved to soluble and particulate fractions, and in both fractions the PDE activity was determined either in the absence or in the presence of $0.2 \mathrm{mM}$ IBMX using $\left[{ }^{3} \mathrm{H}\right] \mathrm{cGMP}$ as the substrate according to the procedure described in Materials and Methods. Control experiments were performed at $0.5 \mu \mathrm{M}$ concentration of the substrate, while the effect of cGMP was assayed in samples additionally supplemented with cGMP to a final concentration of $5 \mu \mathrm{M}$. In the soluble fraction the PDE activity was additionally measured in the presence of either $250 \mu \mathrm{M} \mathrm{Ca}^{2+}$ and $2.4 \mu \mathrm{M}$ bovine calmodulin $\left(\mathrm{Ca}^{2+} / \mathrm{CaM}\right)$ or $100 \mu \mathrm{M}$ EGTA. The data shown are the means \pm S.E. of at least three independent measurements. The normalized results are expressed as picomoles of cyclic nucleotide hydrolyzed per minute in a sample containing $1 \mathrm{mg}$ of total protein. 


\section{Expression of PKG1 in PM}

PKG1 is considered to be the most ubiquitously expressed enzyme regulated by cGMP (Lohmann et al., 1997; Lucas et al., 2000). Therefore, we examined whether this enzyme is present in rat and guinea pig PM. PKG1 is a soluble protein and the cytosolic fractions (extracts) of cells were subjected to Western blot analysis using specific antibody to PKG1 for immunostaining. Surprisingly, there was a lack of specific staining in both PM extracts, although the antibody recognized about 78 $\mathrm{kDa}$ band corresponding to the molecular mass of PKG1 in lung extracts (control) of both species (Fig. 3).

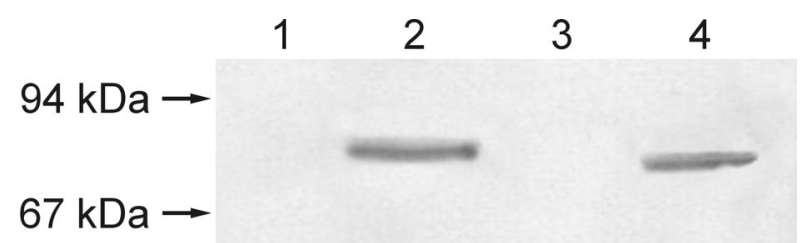

Figure 3. Expression of PKG1 in guinea pig and rat PM.

Extracts containing soluble proteins $(40 \mu \mathrm{g})$ from PM were subjected to SDS/PAGE and Western blotting analysis as described in Materials and Methods using primary antibody to PKG1 (diluted 1:1000). Extracts containing $40 \mu \mathrm{g}$ of soluble proteins from guinea pig and from rat lung were used as reference standards for PKG1 expression. Lanes 1-4 contain extracts of guinea pig macrophages, guinea pig lungs, rat macrophages, and rat lungs, respectively.

\section{DISCUSSION}

Many reports indicate that cGMP is involved in modulation of several functions of macrophages but information concerning the enzymes responsible for the nucleotide metabolism is limited. ANP-regulated particulate GC-A activity was found in rat Kupffer cells (Bilzer et al., 1999; Kiemer et al., 2002), rat peritoneal exudate macrophages (Witwicka et al., 2002), and human dendritic cells (Morita et al., 2003). The argument for a role of this enzyme is strengthened by the observation of Throsby et al. (1993) that macrophages from rat thymus are able to produce ANP themselves and thus the hormone may act through GC-A as a paracrine or an autocrine regulator of macrophage functions. The presence of GC-A and lack of soluble GC was reported for mouse bone marrow-derived macrophages (Kiemer \& Vollmar 1998; Kiemer et al., 2000) but recently other authors showed expression of soluble GC in those cells (Connelly et al., 2003). The activities of both soluble and particulate GCs were observed in human peritoneal macrophages (Houdijk et al., 1990) and in macrophage cell line J774.16 (Mattana \& Singhay, 1993). Furthermore, soluble GC activity was detected in resident rat peritoneal macrophages maintained in culture (Hortelano et al., 1993; Tamion et al., 1998) and in RAW 264.7 cells (Ke et al., 2001). In the light of recent data suggesting different cellular functions for the soluble and particulate GCs (Ivanova et al., 2001; Zolle et al., 2000), it is important to establish which forms of GC are in fact expressed in a cell. In our studies we attempted to determine which enzymes may participate in cGMP metabolism and signaling in inflammatory macrophages provoked to the peritoneal cavity of guinea pig and rat. The peritoneal macrophages induced in these animals are commonly used as models in studies on the role of macrophages in inflammatory processes (Galea \& Feinstein 1999; Germain et al., 1998; Gorczyca et al., 1989; Hortelano et al., 1993; Kelly et al., 1998; Tamion et al., 1998; Turner et al., 1993). Using known activators of pGCs and sGC, we demonstrate that in guinea pig PM the activity of soluble GC, regulated by $\mathrm{NO}$, is markedly higher than activity of pGC. An opposite effect is observed in the case of rat macrophages where sGC activity is completely absent and only GC-A is recognized as an active GC. Based on the observations of O'Dorisio et al., (1984) that during in vitro maturation of human peripheral blood monocytes to macrophages cGMP is synthesized mainly by the sGC in monocytes but by the pGCs in macrophages, one can not exclude the possi- 
bility that macrophage maturation is completed in a shorter time in rat than in guinea pig. This suggestion seems to be supported by the observations that guinea pig PM reveal low GC-B activity (Fig. 1a), which increases during the culture of the cells (Kobiałka \& Gorczyca, unpublished). Further studies are needed to establish whether the distinct expression of sGC and pGC activity in guinea pig and rat PMs is species-specific or rather it reflects differences in kinetics of the maturation of monocyte-derived cells in these species.

Similarly to GCs, also the expression of PDEs was reported to change during maturation of monocytes to macrophages (Gantner et al., 1997). It was suggested recently that cGMP may be hydrolyzed by at least three different isoforms of PDEs in rat peritoneal macrophages (Witwicka et al., 2002) but the presence of cGMP-hydrolyzing PDEs was rather excluded in guinea pig PM (Kelly et al., 1998; Turner et al., 1993). However, the ability of guinea pig PM to synthesize cGMP described here suggests that these cells should express cGMP-hydrolyzing PDEs. Therefore, we verified whether such activity is detectable in guinea pig PM. Our results clearly show that PDEs hydrolyzing cGMP in a cGMP-dependent manner are present in guinea pig $\mathrm{PMs}$, although their activity is much lower than that observed in rat PM. Interestingly, we also detect in guinea pig PM the activity of a $\mathrm{Ca}^{2+} / \mathrm{CaM}$-dependent PDE, which is not present in rat PM.

An important observation is that PKG1 is apparently not expressed in PM of either species. It is documented that this kinase is responsible for cGMP effects in several immune cell types (Fisher et al., 2001; Kamisato et al., 1997; Pryzwansky et al., 1995) and specific antibodies detect PKG1 in cells of different mouse lymphoid organs (Kurowska et al., 2002). However, using the same antibodies we were not able to detect PKG1 in either guinea pig or rat macrophages. Based on this observation, we suggest that in these cells the
cGMP-regulated PDEs might be the effector enzymes for cGMP. The PDE activity is assumed to be the main factor determining the duration of the cGMP and/or cAMP signals. PDEs belonging to six families (PDE2, 5, 6, 10 and 11) are cGMP-regulated and three of them (PDE2, 10, 11) may hydrolyze both cGMP and cAMP (Francis et al., 2000; Soderling \& Beavo 2000). If they are present in PM they may control the concentration of both nucleotides in a cGMP-dependent manner. Thus, cGMP appears as an important regulator of inflammatory response in PM because cAMP is a known mediator of this process in macrophages (Galea \& Feinstein 1999; Hahn et al., 1998; Jaramillo \& Olivier, 2002).

In summary, our results show that cGMP may be synthesized and hydrolyzed in peritoneal macrophages of rat and guinea pig but the profiles of GC and PDE expression in PM of both species are different. Since PKG1 is apparently absent in these cells, the cGMP-regulated PDEs are major candidates to mediate the nucleotide effects in PM.

\section{R E F E R E N C E S}

Bellamy TC, Garthwaite J. (2002) The receptor-like properties of nitric oxide-activated soluble guanylyl cyclase in intact cells. $\mathrm{Mol}$ Cell Biochem.; 230: 165-76.

Bilzer M, Jaeschke H, Vollmar AM, Paumgartner G, Gerbes AL. (1999) Prevention of Kupffer cell-induced oxidant injury in rat liver by atrial natriuretic peptide. Am $J$ Physiol.; 276: 1137-44.

Connelly L, Jacobs AT, Palacios-Callender M, Moncada S, Hobbs AJ. (2003) Macrophage endothelial nitric-oxide synthase auto-regulates cellular activation and pro-inflammatory protein expression. J Biol Chem.; 278: 26480-7.

Dejda A, Matczak I, Gorczyca WA. (2002) P19 detected in the rat retina and pineal gland is a guanylyl cyclase-activating protein (GCAP). Acta Biochim Polon.; 49: 899-905. 
Fisher TA, Palmetshofer A, Gambaryan S, Butt E, Jassoy C, Walter U, Sopper S, Lohmann SM. (2001) Activation of cGMP-dependent protein kinase $\mathrm{I} \beta$ inhibits interleukin 2 release and proliferation of $\mathrm{T}$ cell receptor-stimulated human peripheral T cells. $J$ Biol Chem.; 276: 5967-74.

Francis SH, Turko IV, Corbin JD. (2001) Cyclic nucleotide phosphodiesterases: relating structure and function. Prog Nucleic Acid Res Mol Biol.; 65: 1-52.

Galea E, Feinstein DI. (1999) Regulation of the expression of the inflammatory nitric oxide synthase (NOS2) by cyclic AMP. FASEB J.; 13: $2125-37$.

Gantner F, Kupferschmidt R, Schudt C, Wendel A, Hatzelmann A. (1997) In vitro differentiation of human monocytes to macrophages: change of PDE profile and its relationship to suppression of tumour necrosis factor- $\alpha$ release by PDE inhibitors. $\mathrm{Br} J$ Pharmacol.; 121: 221-31.

Germain N, Bertin B, Legendre A, Martin B, Lagente V, Payne A, Bichot E. (1998) Selective phosphodiesterase inhibitors modulate the activity of alveolar macrophages from sensitized guinea-pigs. Eur Respir J.; 12: 1334-9.

Gorczyca WA, Kobiałka M, Kuropatwa M, Kurowska E. (2003). $\mathrm{Ca}^{2+}$ differently affects hydrophobic properties of guanylyl cyclase-activating proteins (GCAPs) and recoverin. Acta Biochim Polon.; 50: 367-76.

Gorczyca W, Wieczorek Z, Lisowski J. (1989) Cell surface sialic acid affects immunoglobulin binding to macrophages. FEBS Lett.; 259: 99-102.

Hahn PY, Yoo P, Ba ZF, Chaudry IH, Wan P. (1998) Upregulation of Kupffer cell $\beta$-adrenoceptors and cAMP levels during the late stage of sepsis. Biochim Biophys Acta.; 1404: $377-84$.

Heinloth A, Brune B, Fisher B, Galle J. (2002) Nitric oxide prevents oxidized LDL-induced p53 accumulation, cytochrome $c$ translocation, and apoptosis in macrophages via guanylate cyclase stimulation. Atherosclerosis.; 162: 93-101.
Hill JR, Corbett JA, Kwon G, Marshall CA, McDaniel ML. (1996) Nitric oxide regulates interleukin 1 bioactivity released from murine macrophages. J Biol Chem.; 271: 22672-8.

Hortelano S, Genaro AM, Bosca L. (1993) Phorbol esters induce nitric oxide synthase and increase arginine influx in cultured peritoneal macrophages. FEBS Lett.; 320:135-9.

Horton JK, Baxendale PM. (1995) Mass measurements of cyclic AMP formation by radioimmunoassay, enzyme immunoassay, and scintillation proximity assay. Methods Mol Biol.; 41: 91-105.

Houdijk AP, Adolfs MJ, Bonta IL, De Jone HR. (1990) Atriopeptins and nitroprusside provoke opposite changes in cGMP and cAMP levels in human macrophages. Eur $J$ Pharmacol.; 179: 413-7.

Ivanova K, Das PK, Van Den Wijngaard R, Lenz W, Klockenbring T, Malcharzyk V, Drummer C, Gerzer R. (2001) Differential expression of functional guanylyl cyclase in melanocytes: absence of nitric-oxide-sensitive isoform in metastatic cells. $J$ Invest Dermatol.; 116: 409-16.

Jaramillo M, Olivier M. (2002) Hydrogen peroxide induces murine macrophage chemokine gene transcription via extracellular signal-regulated kinase- and cyclic adenosine 5 '-monophosphate (cAMP)-dependent pathways: involvement of NF- $\kappa \mathrm{B}$, activator protein 1 , and cAMP response element binding protein. J Immunol.; 169: 7026-38.

Kamisato S, Uemura Y, Takami N, Okamoto K. (1997) Involvement of intracellular cyclic GMP and cyclic GMP-dependent protein kinase in alpha-elastin-induced macrophage chemotaxis. J Biochem.; 121: 862-7.

Ke XC, Terashima M, Nariai Y, Nakashima Y, Nabika T, Tanigawa Y. (2001) Nitric oxide regulates actin reorganization through cGMP and $\mathrm{Ca}^{2+}$ /calmodulin in RAW 264.7 cells. Biochim Biophys Acta.; 1539: 101-13.

Kelly JJ, Barnes PJ, Giembycz MA. (1998) Characterization of phosphodiesterase 4 in guinea-pig macrophages: multiple activities, 
association states and sensitivity to selective inhibitors. Br J Pharmacol.; 124: 129-40.

Kiemer AK, Baron A, Gerbes AL, Bilzer M, Vollmar AM. (2002) The atrial natriuretic peptide as a regulator of Kupffer cell functions. Shock.; 17: 365-71

Kiemer AK, Hartung T, Vollmar AM. (2000) cGMP-mediated inhibition of TNF-alpha production by the atrial natriuretic peptide in murine macrophages. J Immunol.; 165: $175-81$.

Kiemer AK, Vollmar AM. (1998) Autocrine regulation of inducible nitric-oxide synthase in macrophages by atrial natriuretic peptide. $J$ Biol Chem.; 273: 13444-51.

Kobiałka M, Gorczyca WA. (2000) Particulate guanylyl cyclases: multiple mechanisms of activation. Acta Biochim Polon.; 49: 517-28.

Kobiałka M, Kochanowska IE, Gorczyca WA. (2002) Determination of intracellular cAMP and cGMP using ELISA method. Diagn Lab.; 38: $165-74$.

Koesling D. (1998) Modulators of soluble guanylyl cyclase. Naunyn-Schmiedeberg's Arch Pharmacol.; 358: 123-6.

Kurowska E, Kobiałka M, Zioło E, Strządała L, Gorczyca WA. (2002) The cGMP synthesis and PKG1 expression in murine lymphoid organs. Arch Immunol Exp Ther:; 50: 289-94.

Lohmann SM, Vaandrager AB, Smolenski A, Walter U, De Jonge HR. (1997) Distinct and specific functions of cGMP-dependent protein kinases. Trends Biochem Sci.; 22: 307-12.

Lucas KA, Pitari GM, Kazerounian S, Ruiz-Stewart I, Park J, Schulz S, Chepenik KP, Waldman SA. (2000) Guanylyl cyclases and signaling by cyclic GMP. Pharmacol Rev.; 52: 375-413.

Mattana J, Singhal PC. (1993) Effects of atrial natriuretic peptide and cGMP on uptake of IgG complexes by macrophages. Am J Physiol.; 265: C92-8.

Morita R, Ukyo N, Furuya M, Uchiyama T, Hori T. (2003) Atrial natriuretic peptide polarizes human dendritic cells toward a Th2-promoting phenotype through its receptor guanylyl cyclase-coupled receptor A. J Immunol.; 170: 5869-75

O’Dorisio MS, Fertel R, Finkler E, Brooks R, Vassalo L. (1984) Characterization of cyclic nucleotide metabolism during human monocyte differentiation. J Leukoc Biol.; 35: 617-30.

Paolucci C, Rovere P, De Nadai C, Manfredi AA, Clementi E. (2000) Nitric oxide inhibits the tumor necrosis factor alpha-regulated endocytosis of human dendritic cells in a cyclic GMP-dependent way. J Biol Chem.; 275: 19638-44.

Prpic V, Uhing RJ, Gettys TW. (1993) Separation and assay of phosphodiesterase isoforms in murine macrophages using membrane matrix DEAE chromatography and $\left[{ }^{32} \mathrm{P}\right]$ cAMP. Anal Biochem.; 208: 155-60.

Pryzwansky KB, Kidao S, Wyatt TA, Reed W, Lincoln TM. (1995) Localization of cyclic GMP-dependent protein kinase in human mononuclear phagocytes. J Leukoc Biol.; 57: 670-8.

Soderling SH, Beavo JA. (2000) Regulation of cAMP and cGMP signaling: new phosphodiesterase and new functions. Curr Opin Cell Biol.; 12: 174-9.

Syrovets T, Tippler B, Rieks M, Simmet T. (1997) Plasmin is a potent and specific chemoattractant for human peripherial monocytes acting via a cyclic guanosine monophosphate-dependent pathway. Blood.; 89: 4574-83.

Tamion F, Richard V, Lyuomi S, Hiron M, Bonmarchand G, Leroy J, Daveau M, Thuillez C, Lebreton J-P. (1999) Induction of haem oxygenase contributes to the synthesis of pro-inflammatory cytokines in re-oxygenated macrophages: role of cGMP. Cytokine.; 11: 326-33.

Tenor H, Hatzelmann A, Kupferschmidt R, Stanciu L, Djukanovic R, Schudt C, Wendel A, Church MK, Shute JK. (1995) Cyclic nucleotide phosphodiesterase izoenzyme activities in human alveolar macrophages. Clin Exp Allergy.; 25: 625-33. 
Throsby M, Yang Z, Lee D, Huang W, Copolov DL, Lim AT. (1993) In vitro evidence for atrial natriuretic factor-(5-28) production by macrophages of adult rat thymi. Endocrinology.; 132: 2184-90.

Turner NC, Wood LJ, Burns FM, Gueremy T, Souness JE. (1993) The effect of cyclic AMP and cyclic GMP phosphodiesterase inhibitors on the superoxide burst of guinea-pig peritoneal macrophages. $\mathrm{Br} J$ Pharmacol.; 108: $876-83$.

Vaandrager AB. (2002) Structure and function of the heat-stable enerotoxin receptor/guanylyl cyclase C. Mol Cell Biochem.; 230: 73-83.
Witwicka H, Kobiałka M, Gorczyca WA. (2002) Hydrolysis of cyclic GMP in rat peritoneal macrophages. Acta Biochim Polon.; 49: 891-7.

Yoshioka Y, Yamamuro A, Maeda S. (2003) Nitric oxide at a low concentration protects murine macrophage RAW264 cells against nitric oxide-induced death via cGMP signaling pathway. Br J Pharmacol.; 139: 28-34.

Zolle O, Lawrie AM, Simpson AW. (2000) Activation of the particulate and not the soluble guanylate cyclase leads to the inhibition of $\mathrm{Ca}^{2+}$ extrusion through localized elevation of cGMP. J Biol Chem.; 275: 25892-9. 